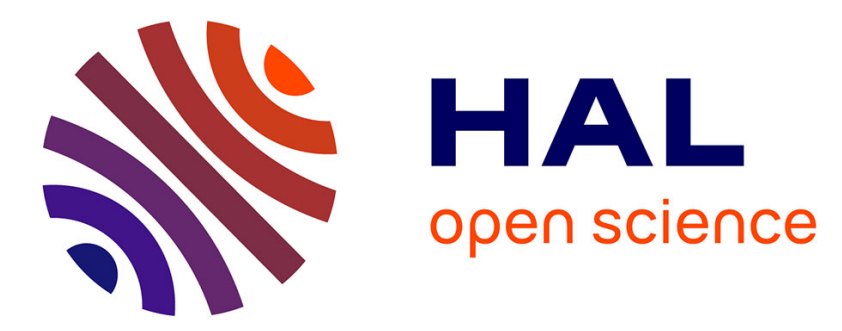

\title{
Reliability of indirect selection in determining the quality of bread wheat for French bread-baking
}

Francois-Xavier F.-X. Oury, Hubert Chiron, Maurice Pichon, Alex Giraud, Pierre Bérard, Annie Faye, Maryse Brancourt-Hulmel, Michel Rousset, Maria Kosutic, Roger Dupuy, et al.

\section{To cite this version:}

Francois-Xavier F.-X. Oury, Hubert Chiron, Maurice Pichon, Alex Giraud, Pierre Bérard, et al.. Reliability of indirect selection in determining the quality of bread wheat for French bread-baking. Agronomie, 1999, 19 (7), pp.621-634. hal-00885957

\section{HAL Id: hal-00885957 https://hal.science/hal-00885957}

Submitted on 1 Jan 1999

HAL is a multi-disciplinary open access archive for the deposit and dissemination of scientific research documents, whether they are published or not. The documents may come from teaching and research institutions in France or abroad, or from public or private research centers.
L'archive ouverte pluridisciplinaire HAL, est destinée au dépôt et à la diffusion de documents scientifiques de niveau recherche, publiés ou non, émanant des établissements d'enseignement et de recherche français ou étrangers, des laboratoires publics ou privés. 


\title{
Original article
}

\section{Reliability of indirect selection in determining the quality of bread wheat for French bread-baking}

\author{
François-Xavier Oury ${ }^{\mathrm{a}^{*}}$, Hubert Chiron ${ }^{\mathrm{b}}$, Maurice Pichon ${ }^{\mathrm{a}}$, Alex Giraud ${ }^{\mathrm{c}}$, Pierre Bérard ${ }^{\mathrm{a}}$, \\ Annie Faye ${ }^{\mathrm{a}}$, Maryse Brancourt-Hulmel ${ }^{\mathrm{d}}$ and Michel Rousset ${ }^{\mathrm{d}}$ \\ With the technical assistance of Maria Kosutic ${ }^{b}$, Roger Dupuy ${ }^{a}$, \\ Josiane Gourdon $^{\mathrm{a}}$ and Fabrice Lagoutte ${ }^{\mathrm{a}}$
}

\footnotetext{
a Station d'amélioration des plantes, Inra, domaine de Crouelle, 63000 Clermont-Ferrand, France

${ }^{b}$ laboratoire de biochimie et technologie des protéines, Inra, BP71627, 44316 Nantes cedex 3, France

' Station d'amélioration des plantes, Inra, domaines d'Epoisses, Bretenières, 21110 Genlis, France

d Station d'amélioration des plantes, Inra, domaine de Brunehaut, 80200 Estrées-Mons
}

(Received 26 May 1999; accepted 30 June 1999)

\begin{abstract}
Putting together information on French bread-baking drawn from 15 years of multi-local experimentation and results of various technological tests (protein content and grain hardness, Pelshenke test, Zeleny sedimentation test and Chopin alveograph), has made it possible to study the effects of genotype and environment on the traits tested as well as the relationships between them. With the exception of protein content and extensibility L of alveograph, genotype $\times$ environment interactions are weak for technological tests, whereas Cnerna bread-baking parameters are strongly influenced by these same interactions. There would appear to be a relatively close connection between the technological tests (except for protein content and extensibility L of alveograph). The technological tests are, however, at best quite weakly linked to bread-baking parameters, making indirect selection quite unreliable. Threshold values making it possible to eliminate only those genotypes showing little chance of high bread-baking quality are defined for the technological tests. In other respects, it seems that grain hardness has no influence on French bread-baking quality. Knowledge of hardness only seems interesting in helping interpret tests at constant hydration, such as Chopin alveograph, in which it introduces bias. († 1999 Inra/Editions scientifiques et médicales Elsevier SAS.
\end{abstract}

\section{French bread-baking / alveograph / Zeleny / Pelshenke / hardness / interaction}

Résumé - Une étude sur la fiabilité de la sélection indirecte pour la valeur en panification française chez le blé tendre. La récapitulation, sur 15 années d'expérimentations multilocales, de données relatives à la panification française et à différents tests technologiques (teneur en protéines et dureté du grain, test Pelshenke, test de sédimentation de Zeleny et alvéographe Chopin), nous a permis d'étudier les effets du génotype et du milieu sur ces caractères et

Communicated by Max Rives (Villeneuves-lès-Avignon, France)

* Correspondence and reprints

oury@clermont.inra.fr 
les relations existant entre eux. A l'exception de la teneur en protéines et de l'extensibilité L de l'alvéographe, les tests technologiques sont peu soumis aux interactions « génotype $\times$ milieu », alors que les différents paramètres de la panification Cnerna sont, eux, fortement soumis à ces interactions. Les relations entre les tests technologiques (excepté pour la teneur en protéines et le L de l'alvéographe) apparaissent fortes. En revanche les tests technologiques ne sont, au mieux, qu'assez faiblement reliés aux paramètres de la panification, ce qui rend peu fiable la sélection indirecte. Des valeurs seuils permettant d'éliminer seulement les génotypes ayant peu de chance d'être de bonne valeur en panification, sont définies pour l'utilisation des tests technologiques en sélection indirecte. Par ailleurs, il apparaît que la dureté du grain n'intervient pas dans la valeur en panification française ; la connaissance de la dureté ne semble importante que pour mieux interpréter les résultats de tests à hydratation constante, comme l'alvéographe Chopin, dans lesquels elle introduit un biais. $\odot 1999$ Éditions scientifiques et médicales Elsevier SAS.

panification française / alvéographe / Zeleny / Pelshenke / dureté / interaction

\section{Introduction}

Selection of bread wheat for French bread-baking quality is carried out almost entirely in an indirect manner, on the basis of various technological tests which are all related to rheological characteristics of the dough. In fact, baking French style bread requires, on the one hand, a large quantity of flour (which rules out testing the first generations for which there are only a few grams per genotype) and, on the other hand, protracted work-time (thus ruling out testing intermediate generations in which the number of genotypes is still too high).

Up to now the reliability of such indirect selection has been little studied. In fact, most published works treat either the relationships between different technological tests but without any actual bread-making $[7,10-12]$ or the relationships between different technological tests along with a bread-baking test $[13,14,23,27]$, but in that case it corresponds to Anglo-Saxon bread-baking which is very different from French bread-baking. Furthermore, only a few works [4, 19-22] take into account, along with the genotype effect, the effect of environment and genotype $\times$ environment interactions on the various technological traits of flours. For French bread-making, only the results of Branlard et al. [8] on 3 years of multi-local experimentation integrate these different aspects and, even though their article was not presented with this goal in mind, enable us to study the reliability of indirect selection for bread-making quality.

The present article covers 15 years of multilocal experimentation for which we possess both the results of French bread-baking tests and the results of technological tests currently used in the breeding process. In order to study the validity of indirect selection, we first looked at the influence of genotype and environment on the various technological traits of the flours, then analysed the relationships between the technological tests and the different parameters of French bread-making.

\section{Materials and methods}

\subsection{Plant material and experimental design}

At Institut national de la recherche agronomique (Inra), breeding for bread wheat is handled by five stations: Clermont-Ferrand (CF), Dijon (DI), Estrées-Mons (EM), Le Moulon (LM) and Rennes (RE). The crossings and follow-up of young generations are carried out at these five sites first in nurseries and then in trials. To evaluate advanced generations a multi-local network is used (for a more complete presentation, see BrancourtHulmel and Lecomte [5]) grouping the five previously mentioned stations along with four other Inra sites: Colmar (CO), Lusignan (LU), La Minière (MI) and Orgeval (OR). At all nine sites trials with two randomised complete blocks are run, with agronomical practices corresponding to those of intensive farming, notably as concerns efficient fungicide and insecticide protection and nitrogen fertilisation adjusted to a goal of high yield.

Lines evaluated in the network are at least F6 generation and the agronomic value of this material, corresponding to lines at the final stage of the Inra breeding process, is perfectly representative of material adapted to North-European conditions. The best lines at the end of the first year of multi-local trials are carried over for 
second year trials, and the number of genotypes is then low enough for French bread-making to be feasible. The bread-making itself is carried out by the Nantes Inra station for a sub-sampling of the nine experimental sites (from four to seven sites, depending on the year). In parallel, several technological tests used for indirect selection of bread-baking quality are run. All of these technological analyses are run on only one of the two blocks of the trials retained.

Our study covers data over 15 years of multi-local experimentation. For each of these years table I gives the number of genotypes present and the sites for which technological analyses were carried out. The 15 years are, in fact, divided into two sub-groups: 1977-1985 (skipping 1979) and 1991-1997. Indeed, we wanted to take into account any possible transformation in the position and dispersion parameters of the different variables under study over time. Preliminary study of the data (results not shown), however, made it clear that no tendency of change in the distribution of the different traits between the two groups of years could be observed. Henceforth, the 15 years will be treated globally, without taking their sub-group structure into account.

\subsection{Technological tests}

Among the tests studied one can distinguish between those requiring limited quantities of grain and little investment in work-time and those requiring more flour and/or longer work-time. The former tests are used for the large number of genotypes found in the early generations of selection, while the latter are used for subsequent generations in which the breeding process has already reduced the number of subjects. In the first group protein content, grain hardness, the Zeleny sedimentation test and the Pelshenke test are considered. In the second the Chopin alveograph is retained.

Note: grain hardness has only been tested in the network since 1993. In fact, until 1985 'hard' wheat types were not grown significantly in France [15]. Since then, an increasing number of 'hard' wheat types have been registered in the French catalogue, which has led breeders to include hardness in their list of traits.

Protein content and hardness were estimated by near infrared reflectance using wholemeal flour produced on a Cyclotec mill with an $0.8 \mathrm{~mm}$ sieve. The methods used are now referenced, respectively, as AACC 39-10 and AACC 39-70 A [2]. The Zeleny sedimentation test [28] was carried out on a flour obtained using a Quadrumat Junior mill (extraction rate approximately $20 \%$ ).

The Pelshenke test [18] was run using wholemeal flour obtained with a MIAG mill equipped with a fluted cone. This test is now described in the method AACC 56-60 [2]. The Chopin alveograph was used according to the method presently referenced as AACC 54-30A

Table I. Locations for which technological analyses have been made and number of genotypes studied, over the 15 years of experimentation.

\begin{tabular}{lccc}
\hline Year & Location & Number of genotypes & Peculiarities \\
\hline 1977 & CF CO DI EM MI RE & 23 & no bread-making for CO \\
1978 & CF CO DI EM MI RE & 27 & no alvéograph and no bread-making for MI \\
1980 & CF CO DI EM LM MI & 27 & dough and bread grades not available \\
1981 & CF CO DI EM LM MI RE & 31 & dough and bread grades not available \\
1982 & CO DI EM LM MI RE & 29 & dough and bread grades not available \\
1983 & CF CO DI EM LM MI RE & 26 & \\
1984 & CF CO DI EM LM MI RE & 19 & dough and bread grades not available for CO \\
1985 & CF CO DI EM LM MI RE & 22 & no Pelshenke and no protein content \\
1991 & DI EM MI RE & 31 & \\
1992 & DI EM MI OR & 47 & no alveograph for OR \\
1993 & CF DI OR RE & 40 & \\
1994 & CF LM OR RE & 39 & farinograph hydration not available \\
1995 & CF DI OR RE & 40 & 34 \\
1996 & CF LM OR RE & 47 & \\
1997 & CF DI LM OR & &
\end{tabular}

$\mathrm{CF}=$ Clermont-Ferrand $; \mathrm{CO}=$ Colmar; $\mathrm{DI}=$ Dijon $; \mathrm{EM}=$ Estrées - Mons $; \mathrm{LM}=$ Le Moulon; $\mathrm{MI}=$ La Minière; $\mathrm{OR}=$ Orgeval; $\mathrm{RE}=$ Rennes. 
[2] on a flour obtained using a Brabender Senior mill (extraction rate of approximately $70 \%$ ). The various parameters for force (W), tenacity $(\mathrm{P})$ and extensibility (L) were calculated first manually (years 1977-1985), then on the basis of recordings made with a Chopin RCV4 apparatus (years 1991-1995) or with a Chopin Alveolink apparatus (years 1996 and 1997).

French bread-baking was carried out according to the standardised Cnerna method (Cnerna NE V03-716) on the same Brabender Senior flour as the alveograph. The quantity of water added to the flour to make dough corresponded to the level of hydration required to give constant consistency with the Brabender farinograph. Among the different parameters recorded during breadbaking, only bread volume and the synthetic quality grades of the dough (on a scale of 100), the bread (on a scale of 200) and their total were retained: this total (on a scale of 300) constitutes the final grade in Cnerna bread-making.

\subsection{Statistical analyses}

For each year, genotype and environment effects were studied using the following variance analysis model:

$$
Y_{i j}=\mu+\alpha_{i}+\beta_{j}+\varepsilon_{i j}
$$

where $\alpha_{i}$ represents the effect of genotype $i, \beta_{j}$ the effect of site $j$ and $\varepsilon_{i j}$ an error term.

Since genotypes were different from year to year, global analysis over the 15 years including a year effect was not possible.

Genotype $\times$ environment interactions could not be tested using variance analysis as there was only one repetition for the technological analyses. Trait stability was therefore studied using inter-location Spearman rank correlation coefficients. This approach shows only the part of genotype $x$ environment interactions which provokes modifications in genotypes classification $[3,6]$, but it is in fact this non-conservation of classifications from one site to another which poses the biggest problem in selection.

\section{Results and discussion}

\subsection{Effect of genotype and environment on the different traits studied}

Variance analysis brings to light location and genotype effects which are highly significant for all variables (table $I I$ ), in accordance with results published by Branlard et al. [8]. The only point to make is that for Cnerna bread-making parameters location effects are not so highly significant certain years. If $\mathrm{F}$ values (table II), or the probabilities associated with the $F$ values for the 15 years (data not presented), are considered, one finds that for yield and protein content location effects are often higher than genotype effects, whereas for all other variables genotype effects are usually higher than those of location.

For the part of genotype $\times$ environment interactions reflected in rank correlation coefficients figure 1 makes it possible to distinguish between three types of variable.

Yield, for which the average of Spearman rank correlation coefficients is very low, indicating poor conservation of genotypes classifications from one site to another and therefore very high levels of genotype $\times$ environment interactions.

Protein content, extensibility L of alveograph and the four variables relative to Cnerna breadmaking, for which average values of rank correlation coefficients are quite low, with wide dispersion of these coefficients. For these six variables there are, hence, high levels of genotype $x$ environment interactions.

Pelshenke, Zeleny, the $\mathrm{P}$ and the $\mathrm{W}$ of alveograph (and to a lesser extent the $\mathrm{P} / \mathrm{L}$ ratio), for which the average values of rank correlation coefficients are high, with moderate dispersion of these coefficients. For these five variables there is a relatively good conservation of genotype classifications from one site to another, indicating low levels of genotype $\times$ environment interactions.

The importance of genotype $\times$ environment interactions is in part connected to the importance of trait variability. In fact, if this variability is evaluated using the variation coefficient (VC), it appears that the classifications for variables with high VC $(0.36$ for Zeleny, 0.36 and 0.37 respectively for the $\mathrm{P}$ and the $\mathrm{W}$ of alveograph, 0.55 for Pelshenke) change less from site to site than do the classifications for variables with lower VC $(0.12$ for protein content, 0.13 for bread volume, 0.2 for yield and $0.21,0.22$ and 0.23 , respectively, for the total grade, the dough grade and the bread grade in 


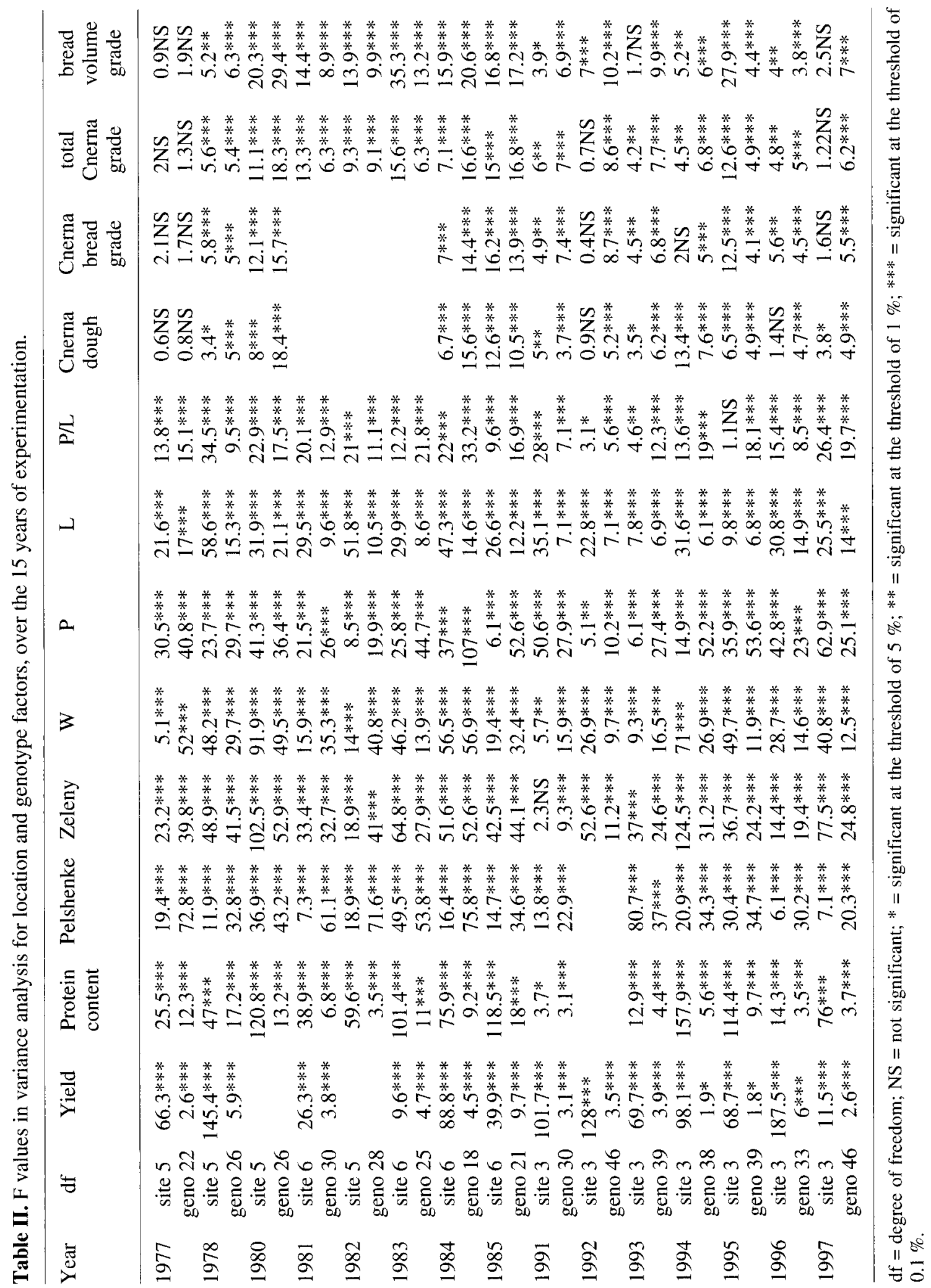


YIELD

average coefficient $=0.34 \quad(n=156)$

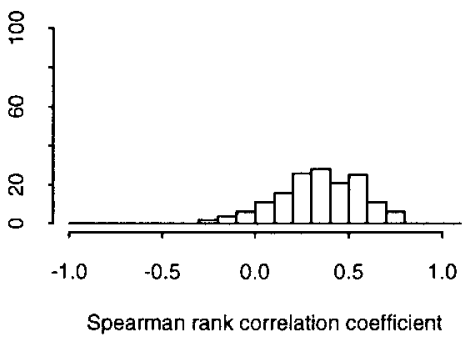

ZELENY

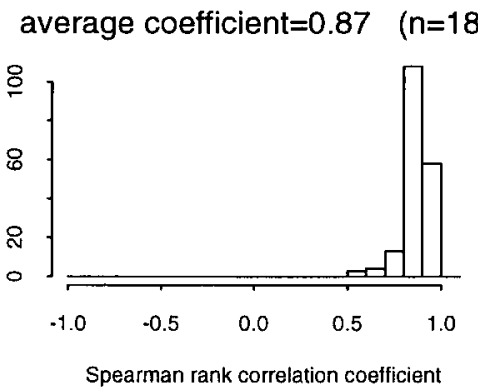

L OF ALVEOGRAPH average coefficient $=0.61 \quad(n=178)$

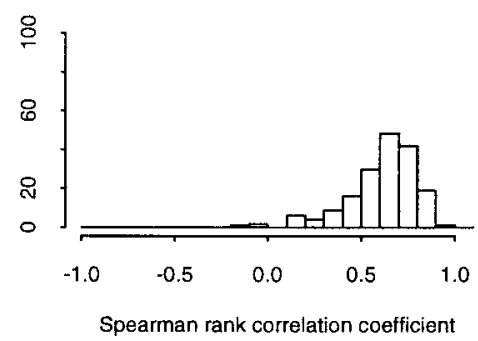

BREAD GRADE average coefficient $=0.54 \quad(n=113)$

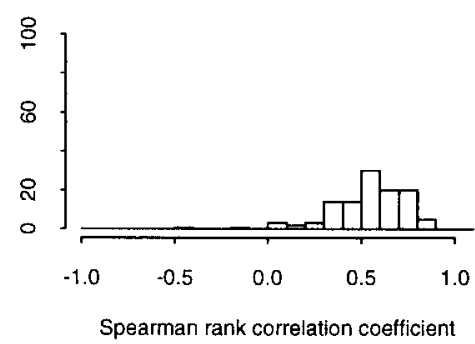

PROTEIN CONTENT average coefficient $=0.52 \quad(n=180)$

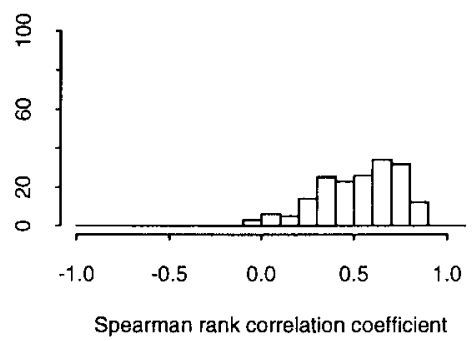

W OF ALVEOGRAPH average coefficient $=0.81 \quad(n=178)$

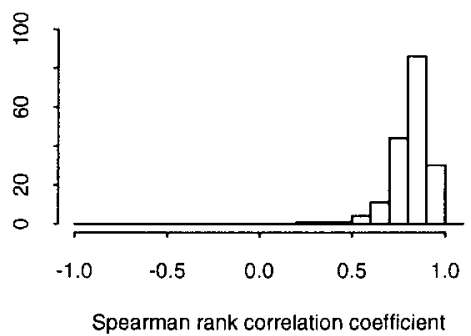

P/L OF ALVEOGRAPH average coefficient $=0.74 \quad(n=178)$

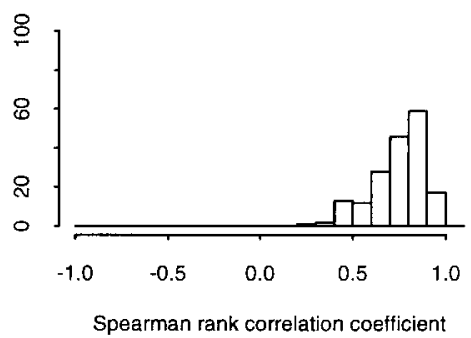

TOTAL CNERNA GRADE average coefficient $=0.52 \quad(n=176)$

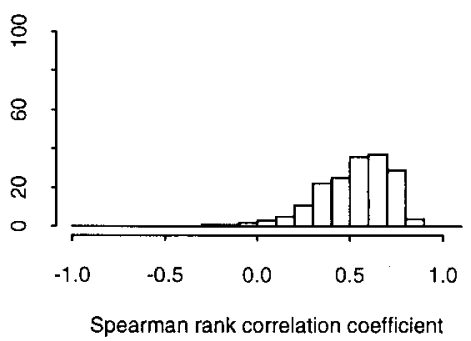

PELSHENKE average coefficient $=0.87 \quad(n=180)$

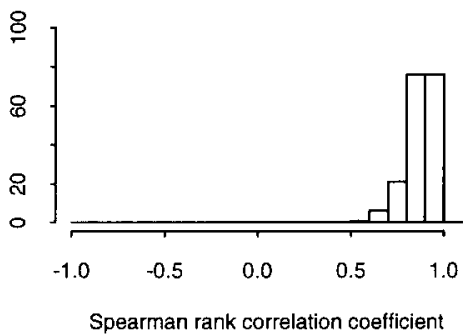

P OF ALVEOGRAPH average coefficient $=0.82 \quad(n=178)$

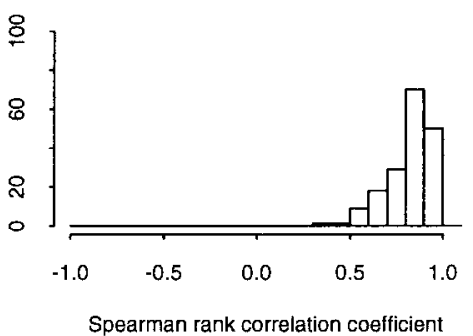

DOUGH GRADE average coefficient $=0.47 \quad(n=113)$

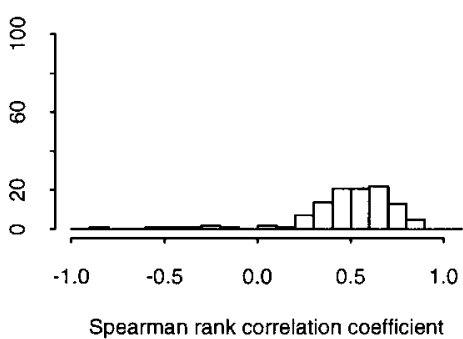

BREAD VOLUME average coefficient $=0.55 \quad(n=176)$

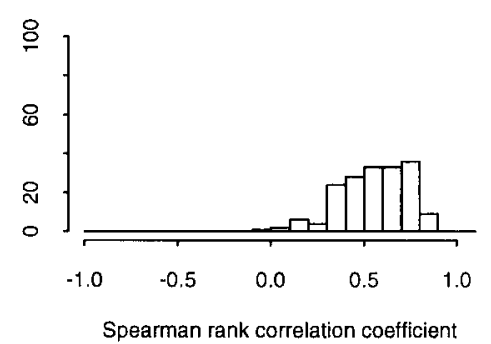

Figure 1. Distribution of the inter-location Spearman rank correlation coefficients and average value of these coefficients, for the different traits studied ( $n$ is the number of pairs of locations, over the 15 years of multi-local experimentation, for which the correlations have been calculated). 
Cnerna bread-making). The only exception concerns the extensibility $\mathrm{L}$ of alveograph, for which the classifications are unstable in spite of a relatively high VC (0.31).

These results highlight one of the difficulties encountered in breeding for French bread-baking quality: one must select for a trait which is strongly affected by genotype $\times$ environment interactions. It is, moreover, an indirect selection and the fact that most of the technological tests used are relatively stable appears to be unfavourable to the development of close correlations between the tests and the Cnerna bread-making parameters.

\subsection{Correlations between the different traits studied}

The first column in table III shows that yield is not linked to any of the technological traits. In particular, there seems to be no conflict between productivity and high French bread-making quality. Only a slightly negative relationship between yield and protein content can be found. This weak negative correlation appears regularly $[11,16,17,22]$ whenever series of genotypes belonging to the category of wheats appropriate to bread-making are studied (by far the largest category in the material under selection). It becomes somewhat stronger only when the samples of genotypes include wheats which are unsuitable for bread-making (often highly productive and low in protein content) and 'strengthener' wheats characterised by high protein levels and low productivity.

For the relationships between the Cnerna breadmaking parameters, table III shows that the dough grade is not closely linked to either the bread grade or bread volume: the average determination coefficients $\left(\mathrm{R}^{2}\right)$ are 0.56 and 0.46 , respectively. In contrast, bread volume is closely linked to the bread grade (average $\mathrm{R}^{2}$ value: 0.81 ), which can be explained by the important weight given to volume in compiling this grade.

For the connections between the different technological tests, table III shows that there is a relatively close relationship between Pelshenke and Zeleny (average $\mathrm{R}^{2}$ value: 0.46 ). In contrast, the
Pelshenke test is practically independent of protein content (average $R^{2}$ value: 0.09 ) and the relationship between protein content and the Zeleny sedimentation test seems quite low (average $\mathrm{R}^{2}$ value: 0.28 ), indicating that Zeleny depends more on the qualitative variation of storage proteins than on their quantitative variation. Furthermore, these three tests appear to be linked to the $\mathrm{W}$ of alveograph: only slightly, as far as protein content is concerned (average $R^{2}$ value: 0.24 ), quite strongly for the Pelshenke test (average $\mathrm{R}^{2}$ value: 0.54 ) and very closely for Zeleny (average $\mathrm{R}^{2}$ value: 0.71 ). Links between these three tests and the tenacity $P$ of alveograph follow the same orientation but at a lower level. On the other hand, none of these tests applicable to young generations are connected to the extensibility $L$ of alveograph. All of these results are coherent with those of Rousset et al. [22] and Branlard and Dardevet [7].

Finally, one sees (table III) that the various technological tests used in indirect selection give only a relatively poor explanation for the variability of French bread-making parameters. For the total grade in Cnerna bread-making it is the $\mathrm{W}$ which gives the highest level of explanation (32\%). However, along with considerably lower requirements in flour and work-time than the alveograph, the Zeleny sedimentation test gives a quite comparable level of explanation $(27 \%)$. With the Pelshenke test, the level of explanation is only $20 \%$, while with protein content it drops to $8 \%$. The percentages of explanation by the technological tests are a little higher in the case of the dough grade, and weaker for the bread grade and bread volume (table III). The weakness in all these correlations is not a recent phenomenon due to the evolution in selected material, as the correlations are not higher for the years 1977-1985 than for the years 1991-1997 (results not presented).

Branlard et al. [8] give correlation values for the relationships between bread volume and several technological tests, obtaining $\mathrm{R}^{2}$ averages of 0.04 with protein content, 0.3 with Pelshenke, 0.38 with Zeleny and 0.38 with the $\mathrm{W}$ of alveograph. These values are a little higher than ours (except for the case of protein content) but, on the one hand, their experimental design covered only 3 years of multi- 


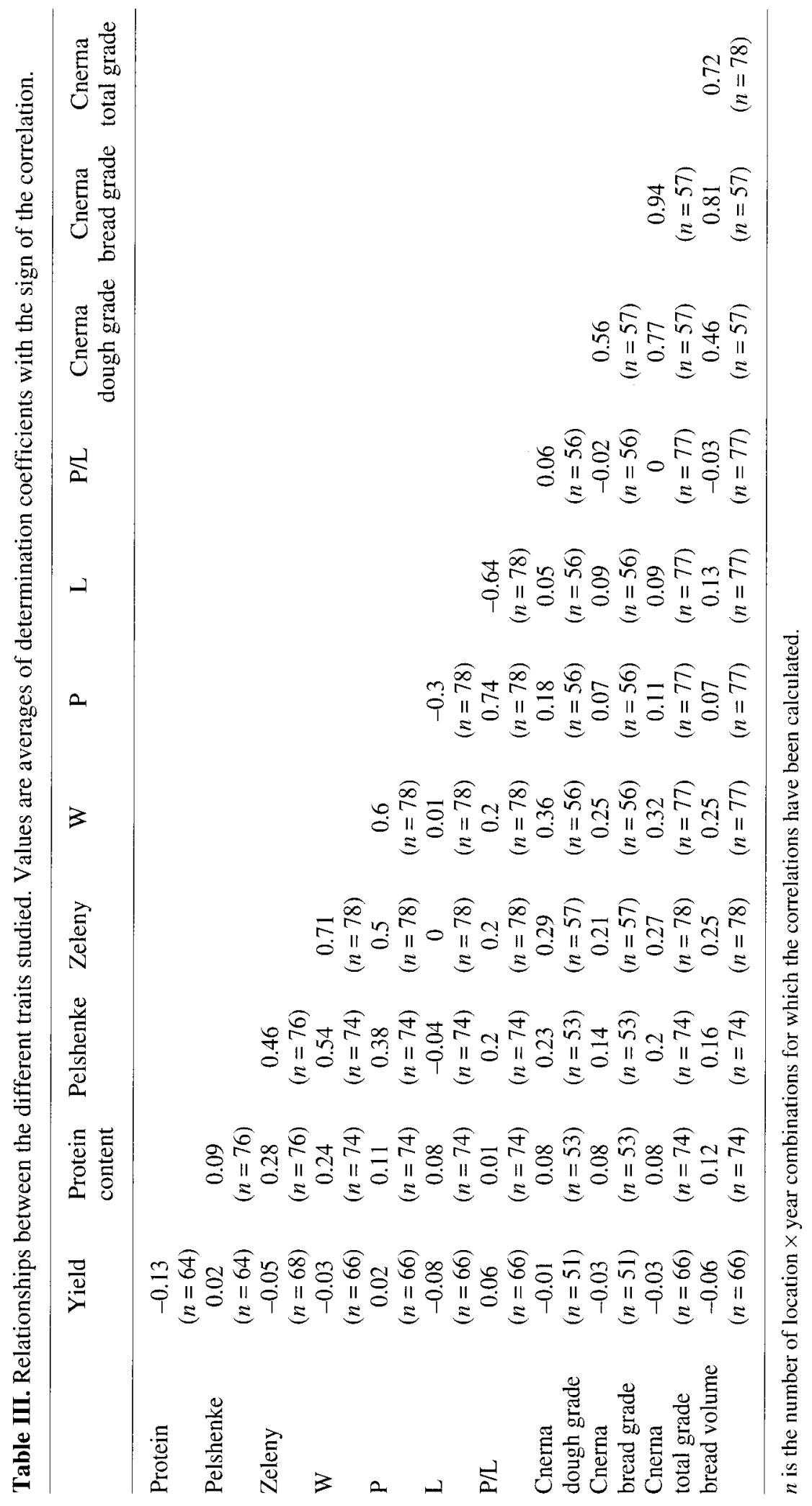


local experimentation (number of site $\times$ year combinations: $n=18$ ) meaning that differences between their values and ours could be simply due to sampling effects; and, on the other hand, their values remain globally coherent with ours insofar as the tests are organised in the same manner and the levels of explanation remain quite low.

All these results point to the principal difficulty encountered in breeding for French bread-baking quality: the technological tests used are quite poorly correlated with the final trait. What is more, since the links between the different tests are quite close (except in the case of protein content and, particularly, the extensibility L), switching to multiple regression results in only moderate progress in explaining the bread-making parameters through different combinations of the technological tests (table IV). For the dough grade, the bread grade and the total Cnerna grade as well as for bread volume, an explanation ceiling is reached at $40 \%$ using the three tests applicable to young generations as explanatory variables and at $60 \%$ using the whole set of tests. The main progress seems to come, moreover, when the different parameters of the alveograph are simultaneously taken into account: one moves from an $\mathrm{R}^{2}$ of 0.32 in simple regression with the $W$ as the explanatory variable to a multiple $\mathrm{R}^{2}$ average of 0.49 whenever $\mathrm{W}, \mathrm{P}, \mathrm{L}$ and $\mathrm{P} / \mathrm{L}$ are taken as explanatory variables.

\subsection{Defining thresholds for technological tests in breeding for French bread-making}

Although the relationships between the technological tests and the various Cnerna bread-making parameters are rather distant, there would seem to be no alternative to indirect selection. It is, therefore, important to exploit the results of the tests as well as possible. Our data constitute a good basis for defining threshold values for the technological tests, below which only those genotypes with little chance of being good for bread-baking would be eliminated. To do so, for each location $\times$ year combination and for each possible value $X$ of the total Cnerna bread-making grade (limiting study to a $\left[X_{\text {inf }}, X_{\text {sup }}\right]$ range of variation which ignores extreme values), the smallest value of the technological test for the genotypes belonging to the $\mathrm{X}$, $\mathrm{X}_{\text {sup }}$ ] interval is retained. The result is a stepped curve like that shown in figure $2 a$ which concerns the Pelshenke test for the 45 genotypes in the 1997 Dijon trial. For each of the values of the Cnerna total grade and for the retained location $\times$ year combination, this stepped curve defines the Pelshenke threshold value under which no genotype with a bread-baking value superior to that considered on the $\mathrm{X}$-axis would be eliminated.

The cloud of points on figure $2 b$ corresponds to the collection of stepped curves for the set of location $\times$ year combinations. For each of the possible bread-making values one thus finds, on a corresponding vertical line, the distribution of the Pelshenke threshold values for the 15 years of multi-local experimentation. When a quantile is selected from this distribution, a threshold is defined - more or less stringently depending on the quantile chosen - under which there is little chance of finding Cnerna bread-making grades superior to that of the $\mathrm{X}$-axis value.

Figure $2 c$ shows the positions of three specific quantiles (first quartile, third decile and median) of the threshold value distribution, for each of the possible bread-making values. The curves thus defined show a strong bending radius, reflecting the low level of correlation between the Pelshenke and the Cnerna total grade. Figure $2 d, e, f$ shows the smooth curves corresponding to these three quantiles for the three traits (Pelshenke, Zeleny and W of the alveograph) which are the least affected by genotype $\times$ environment interactions and which have the closest correlations with the bread-making parameters. These curves make it possible to define threshold values for given bread-baking quality. For the selection of wheats appropriate to bread-making but of only average bread-making quality (Cnerna total grade above or equal to 175) by making a compromise between the values obtained for the three quantiles one can thus retain thresholds of 30 for the Pelshenke test, 20 for the Zeleny sedimentation test and 120 for the $\mathrm{W}$ of alveograph, whereas for the selection of wheats of high bread-making quality (grades above or equal to 200) thresholds of 50 for Pelshenke, 25 for 

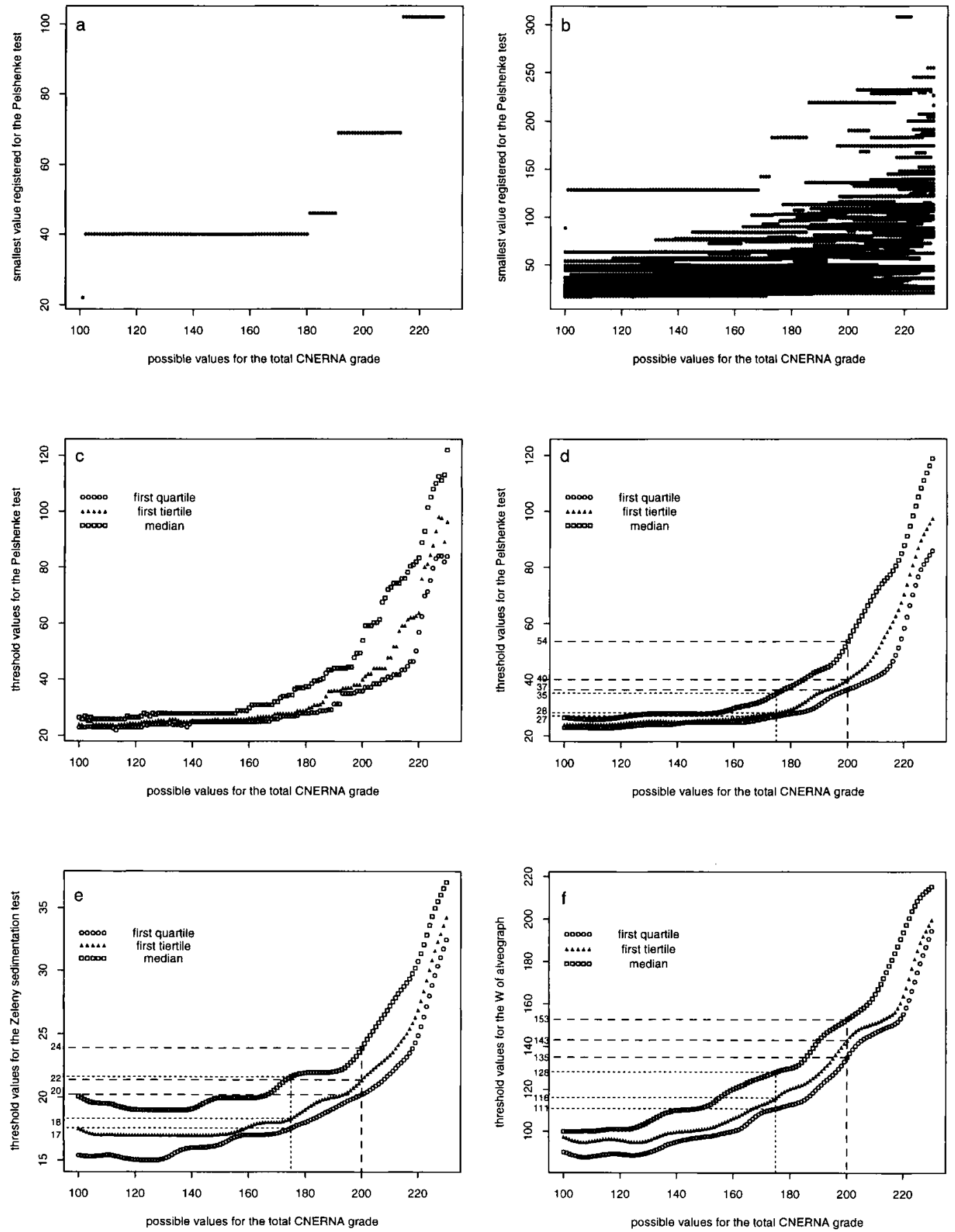

Figure 2. Defining thresholds for the technological tests in breeding for the total Cnerna grade. a) Stepped curve which enables us to define thresholds in the case of Pelshenke test, for the 1997 Dijon trial (45 génotypes). b) Collection of the stepped curves over all location $\times$ year combinations for the Pelshenke test. c) Positions of three specific quantiles for the distributions of threshold values in the case of Pelshenke test. d-f) Threshold values for the Pelshenke test, the Zeleny sedimentation test and the W of alveograph, respectively, for two goals of French bread-making quality: total Cnerna grade above or equal to 175 and total Cnerna grade above or equal to 200 . 
Table IV. Average values for multiple determination coefficients, in explaining Cnerna bread-making parameters by several combinations of technological tests.

\begin{tabular}{|c|c|c|c|c|}
\hline \multirow{2}{*}{$\begin{array}{l}\text { Explanatory } \\
\text { Variables }\end{array}$} & \multirow[b]{2}{*}{ dough grade } & \multicolumn{2}{|c|}{ Explained Variables } & \multirow[b]{2}{*}{ bread volume } \\
\hline & & bread grade & total Cnerna grade & \\
\hline$\%$ proteins + Pelshenke & $\begin{array}{c}0.31 \\
(n=52)\end{array}$ & $\begin{array}{c}0.28 \\
(n=52)\end{array}$ & $\begin{array}{c}0.3 \\
(n=74)\end{array}$ & $\begin{array}{c}0.29 \\
(n=73)\end{array}$ \\
\hline$\%$ proteins + Zeleny & $\begin{array}{c}0.36 \\
(n=52)\end{array}$ & $\begin{array}{c}0.3 \\
(n=52)\end{array}$ & $\begin{array}{c}0.34 \\
(n=74)\end{array}$ & $\begin{array}{c}0.32 \\
(n=73)\end{array}$ \\
\hline Pelshenke + Zeleny & $\begin{array}{c}0.36 \\
(n=52)\end{array}$ & $\begin{array}{c}0.3 \\
(n=52)\end{array}$ & $\begin{array}{c}0.35 \\
(n=74)\end{array}$ & $\begin{array}{c}0.33 \\
(n=73)\end{array}$ \\
\hline $\begin{array}{l}\% \text { proteins + Pelshenke } \\
+ \text { Zeleny }\end{array}$ & $\begin{array}{c}0.4 \\
(n=52)\end{array}$ & $\begin{array}{c}0.36 \\
(n=52)\end{array}$ & $\begin{array}{c}0.4 \\
(n=74)\end{array}$ & $\begin{array}{c}0.38 \\
(n=73)\end{array}$ \\
\hline $\mathrm{W}+\mathrm{P}+\mathrm{L}+\mathrm{P} / \mathrm{L}$ & $\begin{array}{c}0.51 \\
(n=55)\end{array}$ & $\begin{array}{c}0.44 \\
(n=55)\end{array}$ & $\begin{array}{c}0.49 \\
(n=77)\end{array}$ & $\begin{array}{c}0.46 \\
(n=76)\end{array}$ \\
\hline$\%$ proteins $+\mathrm{W}+\mathrm{P}+\mathrm{L}+\mathrm{P} / \mathrm{L}$ & $\begin{array}{c}0.56 \\
(n=51)\end{array}$ & $\begin{array}{c}0.5 \\
(n=51)\end{array}$ & $\begin{array}{c}0.53 \\
(n=73)\end{array}$ & $\begin{array}{c}0.5 \\
(n=72)\end{array}$ \\
\hline Pelshenke $+\mathrm{W}+\mathrm{P}+\mathrm{L}+\mathrm{P} / \mathrm{L}$ & $\begin{array}{c}0.56 \\
(n=51)\end{array}$ & $\begin{array}{c}0.51 \\
(n=51)\end{array}$ & $\begin{array}{c}0.54 \\
(n=73)\end{array}$ & $\begin{array}{c}0.52 \\
(n=72)\end{array}$ \\
\hline Zeleny + W + P + L + P/L & $\begin{array}{c}0.55 \\
(n=55)\end{array}$ & $\begin{array}{c}0.49 \\
(n=55)\end{array}$ & $\begin{array}{c}0.53 \\
(n=77)\end{array}$ & $\begin{array}{c}0.52 \\
(n=76)\end{array}$ \\
\hline $\begin{array}{l}\% \text { proteins }+ \text { Pelshenke } \\
+W+P+L+P / L\end{array}$ & $\begin{array}{c}0.6 \\
(n=51)\end{array}$ & $\begin{array}{c}0.55 \\
(n=51)\end{array}$ & $\begin{array}{c}0.58 \\
(n=73)\end{array}$ & $\begin{array}{c}0.56 \\
(n=72)\end{array}$ \\
\hline$\%$ proteins + Zeleny & 0.6 & 0.54 & 0.57 & 0.56 \\
\hline$+W+P+L+P / L$ & $(n=51)$ & $(n=51)$ & $(n=73)$ & $(n=72)$ \\
\hline $\begin{array}{l}\text { Pelshenke + Zeleny } \\
+\mathrm{W}+\mathrm{P}+\mathrm{L}+\mathrm{P} / \mathrm{L}\end{array}$ & $\begin{array}{c}0.59 \\
(n=51)\end{array}$ & $\begin{array}{c}0.54 \\
(n=51)\end{array}$ & $\begin{array}{c}0.58 \\
(n=73)\end{array}$ & $\begin{array}{c}0.57 \\
(n=72)\end{array}$ \\
\hline $\begin{array}{l}\% \text { proteins }+ \text { Pelshenke } \\
+ \text { Zeleny }+\mathrm{W}+\mathrm{P}+\mathrm{L}+\mathrm{P} / \mathrm{L}\end{array}$ & $\begin{array}{c}0.62 \\
(n=51)\end{array}$ & $\begin{array}{c}0.58 \\
(n=51)\end{array}$ & $\begin{array}{c}0.61 \\
(n=73)\end{array}$ & $\begin{array}{c}0.6 \\
(n=72)\end{array}$ \\
\hline
\end{tabular}

$n$ is the number of location $\times$ year combinations for which the multiple correlations have been calculated.

Zeleny and 150 for the $\mathrm{W}$ can be retained. These threshold values might seem low insofar as they do not allow many genotypes to be eliminated (in the distributions of the technological tests commonly encountered in breeding programmes, most of the genotypes are situated above these thresholds). Threshold values based on a linear relationship between the technological tests and Cnerna breadbaking quality would be much stronger. However, since this linear relationship is of poor quality there would be a high risk of eliminating genotypes which would be good for French bread-making. Using the thresholds we have defined, this risk is quite limited.

For protein content, the low level of correlation with Cnerna bread-making parameters does not rule out using the same type of approach since the definition of threshold values is not based on the existence of a linear relationship between the two traits. One finds threshold values in the order of 10.4 for bread-making grades above or equal to 175 and in the order of 10.8 for bread-making grades above or equal to 200 . However, the high level of genotype $x$ environment interactions for protein content makes using such thresholds rather risky.

\subsection{Role of hardness}

For hardness, variance analysis (results not presented) brings to light highly significant genotype and location effects, with highest importance for genotype, over the 5 years for which we had measurements (1993-1997). For genotype $\times$ environment interactions, hardness is situated in the same 


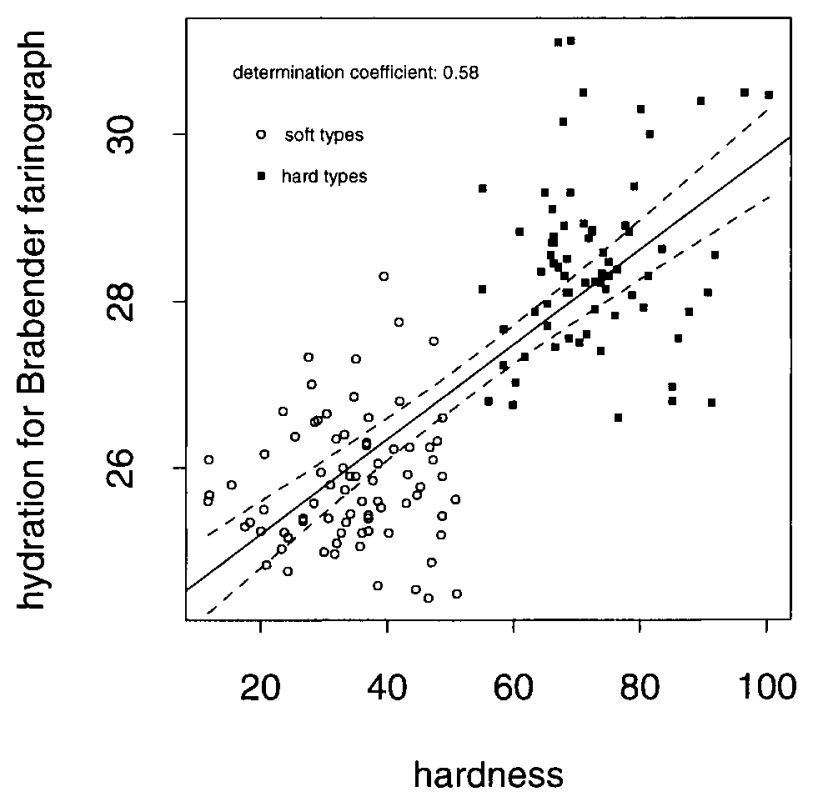

Figure 3. Linear regression between hardness and hydration required to obtain a constant consistency with the Brabender farinograph. Dotted curves delimit $95 \%$ confidence area.

category as Pelshenke, Zeleny, the $\mathrm{W}$ and the $\mathrm{P}$ of alveograph: the average of rank correlation coefficients is $0.85(n=30)$ and the trait thus appears stable.

Hardness has a direct influence on the properties of flour hydration owing to the high percentage of damaged starch in flour from 'hard' wheats $[1,9]$. Figure 3 shows the close relationship that exists between hardness and the hydration required to obtain constant consistency with the Brabender farinograph. The points on the figure correspond to average values of hardness and hydration for the different genotypes present in 1993, 1994, 1995 and 1996 (years for which data on both variables were available). Depiction of the average points is justified insofar as there is a low level of genotype $x$ environment interaction for these two traits (the average of rank correlation coefficients for hydration at farinograph is 0.81 with $n=175$ ).

Due to the major gene involved in the genetic determination of hardness [24-26], 'hard' types can easily be distinguished from 'soft' types in the samples of genotypes from years 1993 to 1997 . It then becomes obvious that hardness has no influ-
Table V. Average value of inter-location Spearman rank correlation coefficients for the different traits studied, according to the hardness type.

\begin{tabular}{|c|c|c|}
\hline & 'Soft' types & 'Hard' types \\
\hline Yield $(n=30)$ & 0.31 & 0.31 \\
\hline Protein content $(n=30)$ & 0.45 & 0.46 \\
\hline Pelshenke $(n=30)$ & 0.81 & 0.77 \\
\hline Zeleny $(n=30)$ & 0.75 & 0.72 \\
\hline W of alveograph $(n=27)$ & 0.73 & 0.64 \\
\hline $\mathrm{P}$ of alveograph $(n=27)$ & 0.8 & 0.76 \\
\hline $\mathrm{L}$ of alveograph $(n=27)$ & 0.62 & 0.55 \\
\hline $\mathrm{P} / \mathrm{L}$ of alveograph $(n=27)$ & 0.77 & 0.72 \\
\hline Dough grade $(n=30)$ & 0.45 & 0.47 \\
\hline Bread grade $(n=30)$ & 0.5 & 0.48 \\
\hline Total Cnerna grade $(n=30)$ & 0.51 & 0.51 \\
\hline Bread volume $(n=30)$ & 0.53 & 0.48 \\
\hline
\end{tabular}

$n$ is the number of pairs of locations for which these correlations have been calculated, over the 5 years of multi-local experimentation for which hardness was available.

ence on the stability of the various traits: average rank correlation coefficients for the years 1993-1997 are the same for the 'hard' group as for the 'soft' group (table $V$ ). Moreover, there is no relationship between hardness and the other technological traits inside a hardness category (table $V I)$. If 'soft' and 'hard' types are taken into account simultaneously, there is still no relationship between hardness on the one hand and yield, protein content and Cnerna bread-making parameters on the other. In contrast, there does appear to be a relationship between hardness and the other technological tests. This relationship is quite distant for the Pelshenke test, the $\mathrm{W}$ and the $\mathrm{L}$ of alveograph but quite close for the Zeleny sedimentation test, the tenacity $\mathrm{P}$ of alveograph and, to a lesser degree, the $\mathrm{P} / \mathrm{L}$ ratio (table VI).

In the case of alveograph parameters, the relationships observed could be explained by the influence of hardness on flour hydration. Indeed, the alveograph is a test run at constant hydration, resulting in under-hydration of 'hard' wheat types. This under-hydration gives 'hard' wheats an artificially high tenacity $\mathrm{P}$ which, in turn, leads to overestimated W levels compared to those of 'soft' wheat types. As alveographic test results are of high importance to the inscription of a genotype in 
Table VI. Relationships between hardness and the different traits studied, within the 'soft' types, within the 'hard' types, and for all the genotypes. Values are averages of determination coefficients with the sign of the correlation.

\begin{tabular}{lccc}
\hline & 'Soft' types & 'Hard' types & All genotypes \\
\hline Yield $(n=20)$ & 0.06 & -0.06 & -0.03 \\
Protein content $(n=20)$ & 0 & 0.14 & 0.08 \\
Pelshenke $(n=20)$ & 0.07 & 0.05 & 0.27 \\
Zeleny $(n=20)$ & 0.01 & 0.06 & 0.45 \\
W of alveograph $(n=19)$ & -0.01 & 0.03 & 0.25 \\
P of alveograph $(n=19)$ & 0.01 & 0.04 & 0.42 \\
L of alveograph $(n=19)$ & -0.04 & 0.01 & -0.18 \\
P/L of alveograph $(n=19)$ & 0.04 & 0.01 & 0.29 \\
Dough grade $(n=20)$ & 0 & -0.01 & 0.1 \\
Bread grade $(n=20)$ & -0.01 & -0.05 & 0.06 \\
Total Cnerna grade $(n=20)$ & -0.01 & -0.04 & 0.08 \\
Bread volume $(n=20)$ & -0.01 & -0.03 & 0.07
\end{tabular}

$n$ is the number of 'location $\times$ year' combinations for which correlations have been calculated.

the French catalogue of varieties, one can partially explain the progress of 'hard' wheat types by this protocol at constant hydration which is advantageous for them.

A similar explanation can be retained for the effect of hardness on Pelshenke, as Pelshenke is also a test run at constant hydration (the lower average $R^{2}$ value could be due to the fact that the operator slightly corrects hydration when dough cannot be obtained, which is only the case with some very 'hard' genotypes).

It is thus obvious that the biases introduced by hardness in a constant hydration test like the alveograph could lead only to a weakening of the relationship between this test and the Cnerna breadmaking parameters (which are taken at constant consistency). Indeed, in the absence of any hardness-bread-making relationship (table VI), the artificially inflated $\mathrm{W}$ values for 'hard' wheats can only represent an additional dispersion factor for the cloud of points whenever, for example, the total Cnerna grade is depicted with reference to the $\mathrm{W}$ of alveograph for a set of genotypes including both "hard" and "soft" wheat types. However, a constant consistency protocol for the alveograph would only have moderate impact on the level of correlation with French bread-baking, as dough strength remains determined essentially by the composition and the rheological properties of the storage proteins of the grain, with hardness of only secondary importance.

\section{Conclusion}

Our study covering 15 years of multi-local experimentation brings to light the difficulty of breeding for French bread-baking quality. On the one hand this trait is substantially affected by genotype $x$ environment interactions, making evaluation complicated. On the other hand the technological tests have, at best, only a slight connection with the various Cnerna bread-making parameters, rendering indirect selection unreliable. One positive point can, however, be emphasised: there is no conflict between productivity and bread-making quality, at least within the range of wheats suitable for bread-making.

Moreover, our results show that hardness does not affect French bread-making quality and that this trait should not be used in the breeding process. Knowledge of hardness is, however, important insofar as it facilitates interpretation of results from tests with constant hydration, such as the alveograph, in which hardness introduces bias. 


\section{References}

[1] Abecassis J., Mabille F., Haddad Y., Autran J.C., Benet J.C., La dureté des blés: état des connaissances actuelles, Industrie des céréales 101 (1997) 11-18.

[2] American Association of Cereal Chemists, Approved Methods of the A.A.C.C., The association, St Paul, MN, 1995.

[3] Becker H.C., Léon J., Stability analysis in plant breeding, Plant Breed. 101 (1988) 1-23.

[4] Bergman C.J., Gualberto D.G., Campbell K.G., Sorells M.E., Finney P.L., Genotype and environment effects on wheat quality traits in a population derived from a soft by hard cross, Cereal Chem. 75 (1998) 729-737.

[5] Brancourt-Hulmel M., Lecomte C., Sélection et stabilité du rendement chez le blé tendre d'hiver, Agronomie 14 (1994) 611-625.

[6] Brancourt-Hulmel M., Biarnès-Dumoulin V., Denis J.B., Points de repère dans l'analyse de la stabilité et de l'interaction génotype $\times$ milieu en amélioration des plantes, Agronomie 17 (1997) 219-246.

[7] Branlard G., Dardevet M., Diversity of grain proteins and bread wheat quality I) Correlation between gliadin bands and flour quality characteristics, J. Cereal Sci. 3 (1985) 329-343.

[8] Branlard G., Rousset M., Loisel W., Autran J.C., Comparison of 46 technological parameters used in breeding for bread wheat quality evaluation, J. Genet. Breed. 45 (1991) 263-280.

[9] Branlard G., Felix I., Leblanc A., Koenig J., Bodet C., Marion D., Mahaut B., La dureté des blés sélectionnés en France: évolution et conséquences, Industrie des céréales 101 (1997) 5-10.

[10] Campbell W.P., Wrigley C.W., Cressey P.J., Slack C.R., Statistical correlations between quality attributes and grain-protein composition for 71 hexaploid wheats used as breeding parents, Cereal Chem. 64 (1987) 293-299.

[11] Carrillo J.M., Rousset M., Qualset C.O., Kasarda D.D., Use of recombinant inbred lines of wheat for study of associations of high-molecular-weight glutenin subunit alleles to quantitative traits 1. Grain yield and quality prediction tests, Theor. Appl. Genet. 79 (1990) 321-330.

[12] Cressey P.J., Campbell W.P., Wrigley C.W., Griffin W.B., Statistical correlations between quality attributes and grain-protein composition for 60 advanced lines of crossbred wheat, Cereal Chem. 64 (1987) 299-301.

[13] Hamer R.J., Weegels P.L., Marseille J.P., Prediction of the breadmaking quality of wheat: the use of HMW glutenin A subunit-based quality scoring system, J. Cereal Sci. 15 (1992) 91-102.

[14] Kieffer R., Wieser H., Henderson M.H., Graveland A., Correlations of the breadmaking perfor- mance of wheat flour with rheological measurements on a micro-scale, J. Cereal Sci. 27 (1998) 53-60.

[15] Mahaut B., Dureté des blés: méthodes de mesure; situation des blés français, Industrie des céréales (1993) 39-44.

[16] Oury F.X., Rousset M., Bérard P., Pluchard P., Doussinault G., Une étude de la qualité des blés hybrides à travers différents tests technologiques, Agronomie 14 (1994) 377-385.

[17] Oury F.X., Carré B., Pluchard P., Bérard P., Nys Y., Leclercq B., Genetic variability and stability of poultry feeding related characters in wheat, in relation to environmental variation, Agronomie 18 (1998) 139-150.

[18] Pelshenke P., A short method for the determination of gluten quality of wheat, Cereal Chem. 10 (1933) 90-96.

[19] Peterson C.J., Graybosch R.A., Shelton D.R., Baenziger P.S., Baking quality of hard winter wheat: response of cultivars to environment in the great plains, Euphytica 100 (1998) 157-162.

[20] Robert N., Structuring genotype $\times$ environment interaction for quality traits in bread wheat, in two multi-location series of trials, Euphytica 97 (1997) 53-66.

[21] Robert N., Denis J.B., Stability of baking quality in bread wheat using several statistical parameters, Theor. Appl. Genet. 93 (1996) 172-178.

[22] Rousset M., Triboï E., Branlard G., Godon B., Influence du génotype et du milieu sur les tests d'appréciation de la valeur d'utilisation du blé tendre (Triticum aestivum em. Thell.) dans les industries de cuisson, Agronomie 5 (1985) 653-663.

[23] Rousset M., Carrillo J.M., Qualset C.O., Kasarda D.D., Use of recombinant inbred lines of wheat for study of associations of high-molecular-weight glutenin subunit alleles to quantitative traits 2 . Milling and bread-baking quality, Theor. Appl. Genet. 83 (1992) 403-412.

[24] Sourdille P., Perretant M.R., Charmet G., Leroy P., Gautier M.F., Joudrier P., Nelson J.C., Sorrells M.E., Bernard M., Linkage between RFLP markers and genes affecting kernel hardness in wheat, Theor. Appl. Genet. 93 (1996) 580-586.

[25] Symes K.J., The inheritance of grain hardness in wheat as measured by the particle-size index, Aust. J. Agric. Res. 16 (1965) 113-123.

[26] Symes K.J., Influence of the gene causing hardness on the milling and baking quality of two wheats, Aust. J. Agric. Res. 20 (1969) 971-979.

[27] Wikström K., Bohlin L., Multivariate analysis as a tool to predict bread volume from mixograph parameters, Cereal Chem. 73 (1996) 686-690.

[28] Zeleny L., A simple sedimentation test for estimating the bread making and gluten qualities of wheat flour, Cereal Chem. 24 (1947) 465-475. 